\title{
Investigation of the Effect of Web 2.0 Supported 5E Learning Model on Students' Success and Opinion in Teaching Pressure Unit in Distance Education
}

\author{
Ceyda BALCI ÇÖMEZ* \\ Institute of Education, Department of Science Education, Marmara University, PhD. Student, \\ Istanbul, Turkey, \\ ORCID: 0000-0001-9550-7514 \\ Erkan ÇAVUMIRZA \\ Institute of Education, Department of Science Education, Marmara University, PhD. Student, \\ Istanbul, Turkey, \\ ORCID: 0000-0001-7688-6723
}

\section{Mehtap YILDIRIM}

Department of Science Education, Marmara University, Istanbul, Turkey, ORCID: 0000-0001-7398-8396

Article history Received:

12.05.2021

Received in revised form: 06.07.2021

Accepted:

08.07.2021

Key words:

Academic achievement;

Constructivist learning approach;

Distance education;

Pressure unit;

Science education;

Web 2.0 tools;

5 e model
The purpose of this study is to examine the effects of using Web 2.0 tools in accordance with the 5E learning model on the academic success and views of students in teaching the Pressure unit to eighth-grade students in distance education. A total of 41 students, 21 of whom are in the experiment group and 20 of them are in the control group, studying in the eighth grade in a state secondary school in Sakarya, Turkey were included. The activities created with Web 2.0 tools in accordance with the $5 \mathrm{E}$ learning model were applied to the experimental group, and the activities in the science lesson curriculum were applied to the control group through distance education. Explanatory sequential mixed method design was used. The quantitative data of the research were collected by the Pressure Unit Achievement Test. The achievement test was applied to the both groups before and after the process. Qualitative data were collected with a structured interview form with all of the students in the experimental group at the end of the process. The quantitative data were analyzed with t-test and analysis of covariance (ANCOVA). Descriptive analysis was used for qualitative data. Based on the results, it was determined that the academic achievement of the experimental group students increased by showing a significant difference compared to the control group students. It was seen that the experimental group students' opinions about the activities created with web 2.0 tools are generally positive. In line with the results obtained as a result of the study, it is

\footnotetext{
*Correspondency: cydbalci@gmail.com
} 
recommended that Web 2.0 tools are frequently used by teachers in the science course, and at the same time, researchers are recommended to study the effects of other learning models on success or other variables in different subjects and grade levels.

\section{Introduction}

The rapidly developing technology in recent years affects many areas. Education comes first among them. Especially today, when the COVID-19 pandemic is experienced, thanks to technology, educations have started to be given through distance education (Bakioğlu \& Çevik, 2020). Distance education is defined as internet-based education with the help of Internet technologies and technological tools such as computers, mobile phones, and tablets (Newb, Stepich, Lehman \& Russell, 2006). In distance education, unlike traditional classroom teaching, there is almost no face-to-face interaction between teacher and student. Students can follow the lessons as often as desired, independent of the place, within the time period that suits them. In distance education learning materials are designed for students to work alone though. This may cause students to learn incorrectly (Stewart, Goodson, Miertschin, Norwood \& Ezell, 2013). For this reason, it is necessary to determine the contribution of the technologies selected to be used in the educational process to ensure effective and efficient learning in distance education, to the achievement of the course outcomes, content and teaching activities (Pamuk, Ülken \& Dilek, 2012). In the distance education process, a working environment can be prepared for students to enjoy while learning, by using audio, video, graphics, animations, digital materials enriched with structures designed to receive instant feedback. With the inclusion of this type of technology in learning environments, students can achieve permanent and meaningful learning by living in accordance with their individual characteristics and learning pace. In addition, contemporary learning environments and conditions suitable for the needs of the 21 st century allow students to be motivated (Alpar, Batdal \& Avc1, 2007). One of these technologies is Web 2.0 tools.

Today's internet technologies, which are also referred to as Web 2.0 applications; have advantages such as easy communication, fast information sharing and easy access to necessary data, active data design, information recording, measurement and evaluation, and visuality (Ajjan \& Hartshorne, 2008; Altun, 2008). The concept of Web 2.0 was first expressed in a conference by Tim O'Reilly in 2004 (O'Reilly, 2005). Web 2.0 is an environment where existing web content can be produced and changed in order to make web technology more functional and usable. In this environment, users can easily access and share the content produced (Karaman, Yildırım \& Kaban, 2008). Web 2.0 tools preferred in the field of education in recent years, include mind maps, board, poster, cartoon, animation creation, story writing, virtual classrooms, blogs, presentations, tests and puzzles. Bubbl.us, Mindmeister, Pooplet for creating mind maps; Padlet, Blenspace for the board; Canva, Word Art, Tondoo, Storyboard That, Storybird for poster, cartoon and story; Classdojo, Edmodo, Beyazpano for virtual classrooms; for blogs, Tumblr, Blogger; for effective presentation and animation, Prezi, Powtoon; applications such as Kahoot, Quizlet, Flippquiz, Google Form can be used to create tests and puzzles (Benzer, 2017). Digital materials with visually rich content prepared with Web 2.0 tools enable students to learn more permanently by participating in the education environment with more than one sense organ (Elmas \& Geban, 2012). However, one of the most precautionary benefits of Web 2.0 tools for education is that students and teachers go out of the classroom and share information in interaction. In this way, activities developed with Web 2.0 tools can be accessed by all users who use these tools, contribute to 
the content and make changes for their own use (Horzum, 2010; Elmas \& Geban, 2012; Eze, 2016). Nowadays, where the students are actively encouraged to participate in learning environments, Web 2.0 tools always support teachers and students thanks to their advantages and convenience in education. This situation provides convenience in terms of feedback and feedback in education and minimizes the student-teacher interaction problem in distance education. At this point, it is proposed that Web 2.0 applications are a technology that supports the change in education and should be integrated into educational environments (Elmas \& Geban, 2012; Eze, 2016; Sönmez \& Çakır, 2021).

In today's world, where science and technology are rapidly developing, societies attach great importance to science education in order to raise qualified individuals who research and question information, know the ways to access information, have critical thinking skills, understand and use technology, and have positive attitudes and values in order not to stay behind the age (MEB, 2017; OECD, 2019). One of the preferred learning models in science education where the constructivist approach is adopted is the $5 \mathrm{E}$ model. This model consists of an introduction in which prior knowledge is revealed by employing a sense of curiosity, exploration in which possible misconceptions are eliminated and students take an active role, the teacher explains the concepts in a clear and comprehensible manner, deepening in which students adapt the concepts to daily life, and evaluation stages in which students' learning developments are evaluated (Bybee, 2014). The 5E learning model encourages students to do research with interesting and intriguing activities related to daily life at each stage mentioned and enables them to construct their own concepts (Martin, 2012). Liu, Peng, Wu, and Lin (2009) stated in their study that learning activities based on the 5E learning model increased students' knowledge and comprehension levels and their scientific performance. In his metaanalysis study, Saraç (2017) concluded that the 5E learning model has a high effect on students' learning products. He additionally mentioned that the $5 \mathrm{E}$ model has a positive effect on increasing student achievement. However, Wilson, Taylor, Kowalski, and Carlson (2010) emphasized that using the 5E learning model in science education provides students with meaningful learning and increases students' interest in the course. The aims of the constructivist approach adopted in education and the origins of Web 2.0 tools support each other (Lu, Lai, \& Law, 2010). In the constructivist approach, students are encouraged to be active in the learning process by considering their individual differences, and Web 2.0 tools provide opportunities such as creating personalized content and rearranging the contents (Horzum, 2010). Based on this, it can be said that Web 2.0 tools can be used to develop activities suitable for the 5E learning model steps (Kutlu Demir, 2018).

In the literature, in studies on the use of Web 2.0 tools in education, teachers (Çalışkan, Güney, Sakhieva, Vasbieva, \& Zaitseva, 2019; Saraçoğlu, 2019), teacher candidates (Aytan \& Başal, 2015; Yükseltürk, Altık \& Üçgül, 2017; Bünül, 2019;) and students (Küçük, Kapakin \& Göktaş, 2015; Bugawa \& Mirzal, 2017; Saraçoğlu, 2019; Özçınar, Sakhieva, Pozharskaya, Popova, Melnik \& Matvienko, 2020; Özenç, Dursun \& Şahin, 2020), teachers' frequency of using Web 2.0 tools in their lessons and their awareness of these tools (Horzum, 2010), development of 21 st century skills (Kutlu Demir, 2018), students 'information literacy selfefficacy (Gülnar \& Acar, 2018), students' academic achievements (Baig, 2011; Ballıel Ünal, 2017). ; Gündoğdu and Korucu, 2018; Gürleroğlu, 2019; Özdem Köse, 2019; Özenç, Dursun, \& Şahin, 2020), the effects of digital literacy (Gürleroğlu, 2019), on course motivation (Küçük, Kapkin, \& Göktaş 2015; Gü rleroğlu, 2019; Kaynar, 2019; Mete \& Batıbay, 2019) and apparently it has a positive effect on these variables. In addition, some studies were found investigating the effect of using Web 2.0 tools on the learning process (Karaman, Y1ldirım, \& Kaban, 2008; Zhao, Yang, \& Wang, 2010; Chunyan, Haitao, Guolin, 2014; Kaynar, 2019; 
Sar1, 2019; Pürbudak, 2020). However, in the literature, it was determined that there are a limited number of studies on the use of Web 2.0 tools in science education (Bolatli \& Korucu, 2018; Özdem Köse, 2019; Gürleroğlu, 2019). In their work with middle school students, Bolatl and Korucu (2018) found that students' views on the use of STEM activities supported by Web 2.0 tools for teaching purposes were positive. Özdem Köse (2019) found in her study that the argumentation activities she developed using Web 2.0 tools in teaching the Force and Energy unit had a positive effect on student achievement, conceptual meanings and attitudes towards science lesson. Gürleroğlu (2019) examined the effect of using Web 2.0 applications in accordance with the 5E model in teaching the unit of "Force and Energy" on the academic achievements, motivations, attitudes and digital literacy of seventh grade students. In the study, it was concluded that science teaching carried out with Web 2.0 applications has a positive influence on student achievement, motivation and views. Moreover, there are articles in the literature showing that science teaching in distance education has a positive effect on student achievement. Aktaş (2013) found that the web-based distance education method increased the academic success of students. Similarly, Balliel Ünal (2017) examined the effect of using web-based distance education in the item exchange unit, on student' academic achievement. Lessons were taught with web-based distance education in the experimental group and traditional methods in the control group. At the end of the study, they determined that web-based distance education made a significant difference in student achievement. However, in the literature, there has been no study examining the effects of the activities created with Web 2.0 tools in accordance with the 5E learning model of the Pressure unit on student achievement and views in distance education. Therefore, it is thought that this research will provide new insights about the use of Web 2.0 tools in science education.

\section{Aim and Study questions}

The aim of this study is to examine the effects of the activities created with Web 2.0 tools in accordance with the 5E learning model on the academic success and views of students in teaching the Pressure unit to eighth grade students in distance education.

For this purpose, in the study, "What are the effects of the activities created with Web 2.0 tools in accordance with the $5 \mathrm{E}$ model on the success and views of the students in teaching the Pressure unit of eighth grade students in distance education?" question has been investigated.

In parallel to these purposes the study has sub-questions are given below.

(1) Do the scores of the experiment students and the control students from the achievement test for the Pressure unit significantly vary?

(2) What are the opinions of the experiment students towards the activities and science lesson developed with Web 2.0 tools suitable for the 5E model?

\section{Method}

\section{Research Model}

In this study, in which the effects of the activities created with Web 2.0 tools in accordance with the 5E model on teaching the Pressure unit to eighth grade students in distance education on the success and views of the students, an explanatory sequential pattern from mixed method research was used. Creswell (2017) emphasized that collecting different types of data would make a research problem better understandable, rather than using only 
qualitative or only quantitative data in mixed method studies. In the descriptive sequential design, qualitative results are aimed at explaining the quantitative results, firstly the quantitative data for the research question are collected and necessary analyses are made in the process, and the qualitative data are collected and analyzed in the second stage (Creswell, 2017). The research design is given in figure 1.

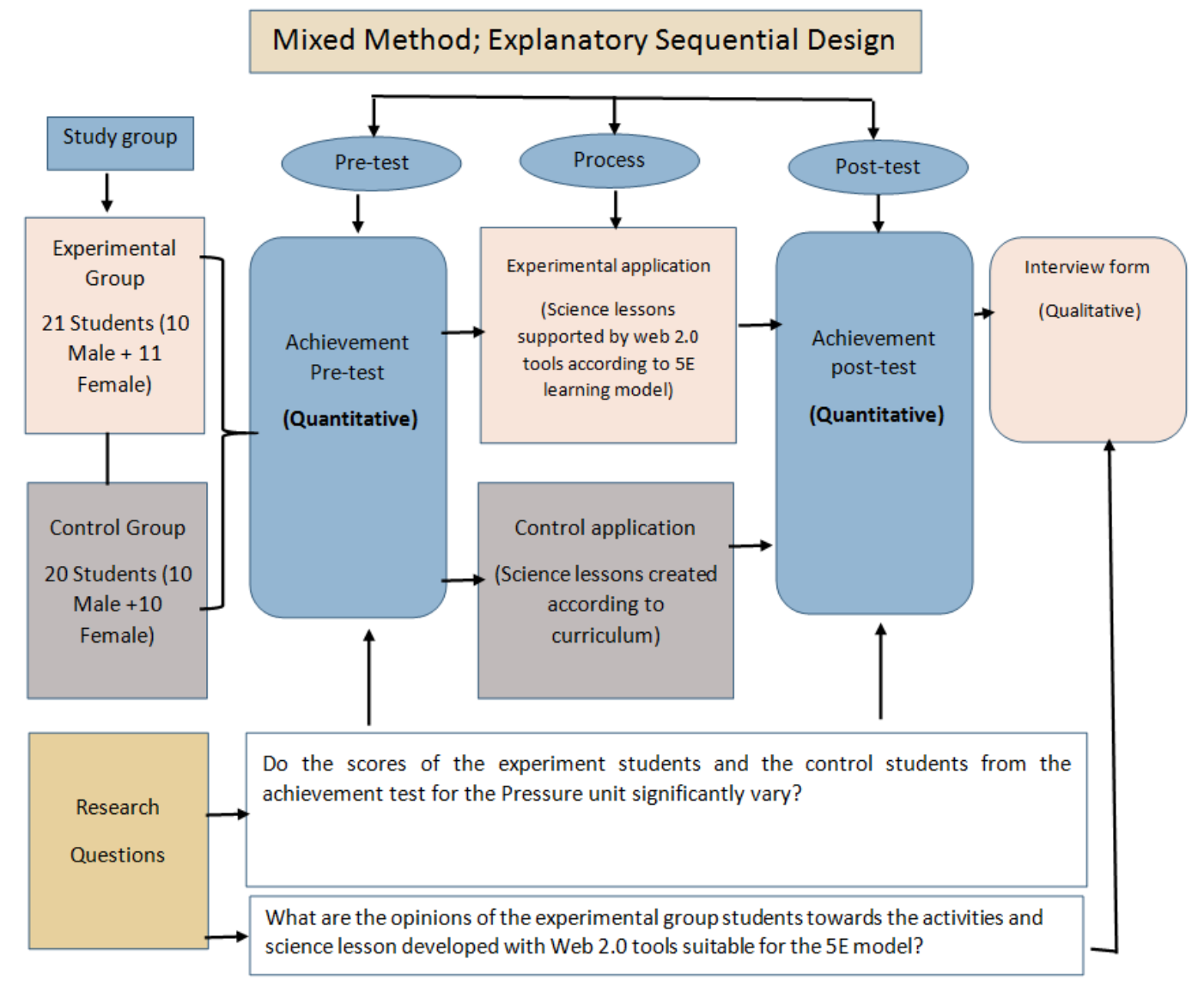

Figure1. The research design

In the quantitative section of the study, a pre test-post test control group quasi-experimental design was applied to examine the effect of the activities created with Web 2.0 tools in accordance with the $5 \mathrm{E}$ model on teaching the Pressure unit to eighth grade students in distance education. In the quasi-experimental design, paired groups are used when they cannot be chosen randomly (Büyüköztürk vd, 2019). Since the students in the study group could not be chosen randomly, a quasi-experimental design was used. In the qualitative dimension, in order to support quantitative data, the opinions of the experimental group students about the activities and science lesson and how they evaluate this process (Creswell, 2017).

\section{Study group}

A total of 41 students, 21 of which experiment and 20 are control groups, in the distance education process in the eighth-grade branch of a state secondary school in Sakarya province of Turkey in the 2020-2021 academic year participated in the study. It has been paid attention to that both classes are at a medium level in terms of academic success. Appropriate sampling was used in the selection of the study group. Appropriate sampling is a method that 
facilitates the researcher in terms of time and effort in reaching a suitable sample (Büyüköztürk vd., 2019). Researchers prepared a Personal Information form and this form was applied to the students before the application. The information obtained regarding the study group is shown in Table 1.

Table1. The information of the study group

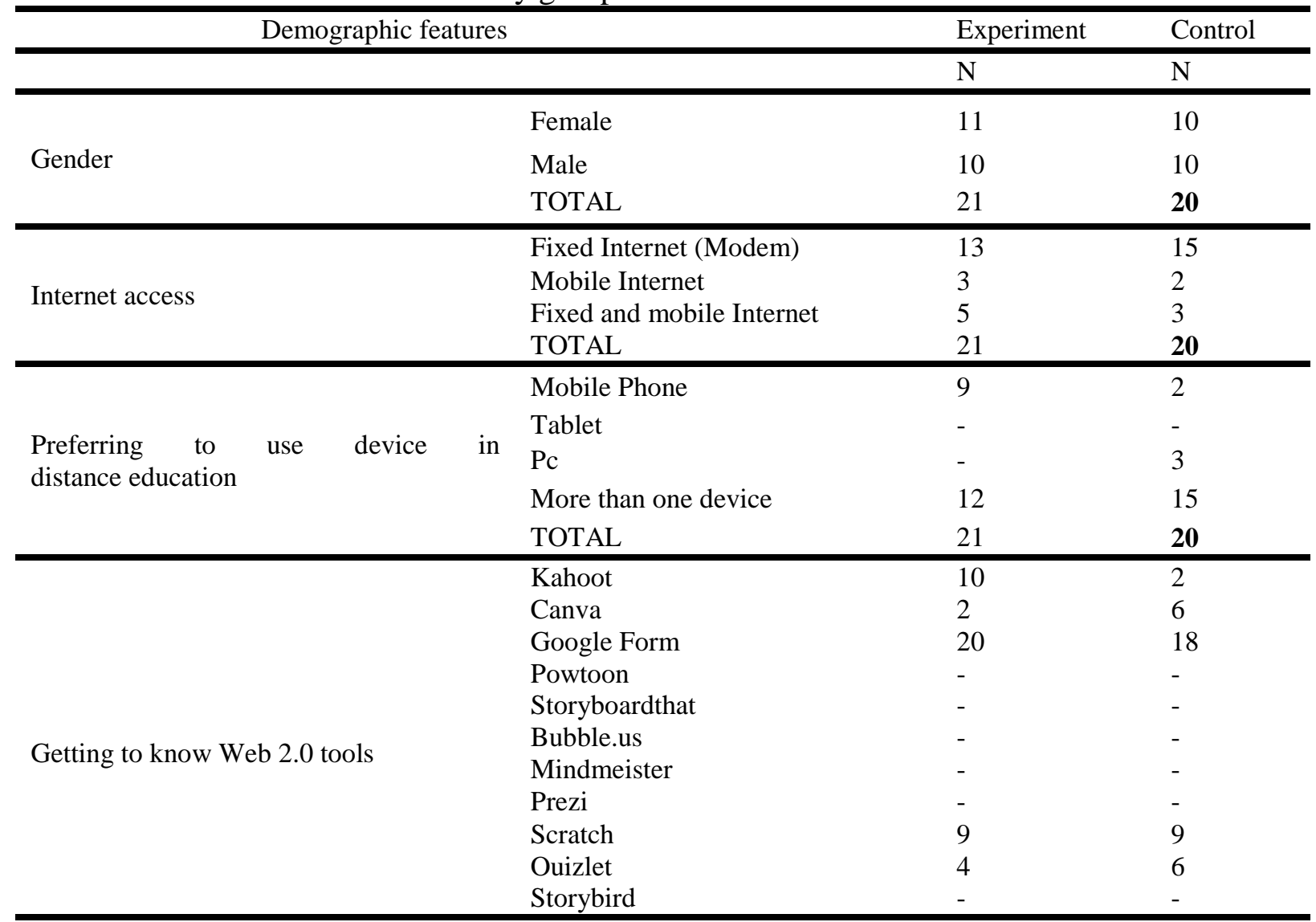

According to Table 1, it is seen that the experimental group consists of a total of 21 students, including 11 females and 10 males, and the control group consists of 20 students, 10 females, and 10 males. Experimental and control group students mostly use the fixed internet ( $\mathrm{n}_{\text {experiment }}$ $=13 ; \mathrm{n}_{\text {control }}=15$ ) for internet access. Similarly, the number of students who prefer to use more than one device in distance education is highest for both groups ( $\mathrm{n}_{\text {experiment }}=12 \mathrm{n}_{\text {control }}$ $=15$ ). Experiment and control group students have the most knowledge about Google Form from Web 2.0 tools ( $\left.\mathrm{n}_{\text {experiment }}=20, \mathrm{n}_{\text {control }}=18\right)$.

\section{Applications Process}

The study was conducted with distance education in the Pressure unit of the eighth grade science lesson. In the lessons in the experimental group, activities created with Web 2.0 tools in accordance with the $5 \mathrm{E}$ model were used, and the activities in the course book were used in the lessons in the control group. The study was carried out for 16 lesson hours. The "Pressure Unit Success Test" developed by Özcan, Koca and Söğüt (2019) was applied to both groups as a pre and post test in order to examine whether there is a significant difference between the achievements of the experimental and control group students. At the end of the study, structured interviews were conducted with all of the experimental group students in order to examine the students' views on the activities created by researchers. 
In the study, Storyboardthat, Storybird, Canva, Minmeister, Bubbl, Prezi, Powtoon, Scracht, Google Form, Kahoot, Quizlet applications were used in the development of activities suitable for the 5E model. Information on which Web 2.0 tools are used in the issues related to the Pressure unit in the stages of the 5E plan is given in Table 2.

Table2. Web 2.0 tools and activities used in 5E plan stages related to Pressure unit

\begin{tabular}{|c|c|c|c|c|c|}
\hline Issue & Engage & Explore & Explain & Elaborate & Evaluate \\
\hline \multirow{3}{*}{$\begin{array}{l}\text { Solid } \\
\text { Pressure }\end{array}$} & $\begin{array}{l}\text { The concept } \\
\text { cartoon } \\
\text { prepared with } \\
\text { the } \\
\text { Storyboardthat }\end{array}$ & $\begin{array}{l}\text { The concept } \\
\text { story } \\
\text { prepared } \\
\text { with } \\
\text { Storybird }\end{array}$ & $\begin{array}{l}\text { The animation } \\
\text { prepared with } \\
\text { Powtoon }\end{array}$ & $\begin{array}{l}\text { The } \\
\text { presentation } \\
\text { prepared with } \\
\text { Prezi }\end{array}$ & $\begin{array}{l}\text { The new } \\
\text { generation } \\
\text { questions test } \\
\text { prepared with } \\
\text { Google Form }\end{array}$ \\
\hline & & $\begin{array}{l}\text { Poster } \\
\text { prepared } \\
\text { with Canva }\end{array}$ & $\begin{array}{ll}\text { The concept } & \text { Map } \\
\text { prepared } & \text { with } \\
\text { Bubbl } & \end{array}$ & $\begin{array}{l}\text { The animation } \\
\text { prepared with } \\
\text { Powtoon }\end{array}$ & $\begin{array}{l}\text { The electronic } \\
\text { cards prepared } \\
\text { with Quizlet }\end{array}$ \\
\hline & & & & $\begin{array}{l}\text { The game } \\
\text { prepared } \\
\text { Scracht }\end{array}$ & $\begin{array}{l}\text { The } \\
\text { competition } \\
\text { prepared with } \\
\text { Kahoot }\end{array}$ \\
\hline \multirow{3}{*}{$\begin{array}{l}\text { Liquid } \\
\text { Pressure }\end{array}$} & $\begin{array}{l}\text { The concept } \\
\text { cartoon } \\
\text { prepared with } \\
\text { the } \\
\text { Storyboardthat }\end{array}$ & $\begin{array}{l}\text { The concept } \\
\text { story } \\
\text { prepared } \\
\text { with } \\
\text { Storybird }\end{array}$ & $\begin{array}{l}\text { The presentation } \\
\text { prepared with } \\
\text { Prezi }\end{array}$ & $\begin{array}{l}\text { The animation } \\
\text { prepared with } \\
\text { Powtoon }\end{array}$ & $\begin{array}{l}\text { The new } \\
\text { generation } \\
\text { questions test } \\
\text { prepared with } \\
\text { Google Form }\end{array}$ \\
\hline & & $\begin{array}{l}\text { Poster } \\
\text { prepared } \\
\text { with Canva }\end{array}$ & $\begin{array}{l}\text { The concept Map } \\
\text { prepared with } \\
\text { Minmeister }\end{array}$ & $\begin{array}{l}\text { The } \\
\text { competition } \\
\text { prepared with } \\
\text { Scracht }\end{array}$ & $\begin{array}{l}\text { The electronic } \\
\text { cards prepared } \\
\text { with Quizlet }\end{array}$ \\
\hline & & & & & $\begin{array}{l}\text { The } \\
\text { competition } \\
\text { prepared with } \\
\text { Kahoot }\end{array}$ \\
\hline \multirow{3}{*}{$\begin{array}{l}\text { Gas } \\
\text { Pressure }\end{array}$} & $\begin{array}{l}\text { The concept } \\
\text { cartoon } \\
\text { prepared with } \\
\text { the } \\
\text { Storyboardthat }\end{array}$ & $\begin{array}{l}\text { The concept } \\
\text { story } \\
\text { prepared } \\
\text { with } \\
\text { Storybird }\end{array}$ & $\begin{array}{l}\text { The presentation } \\
\text { prepared with } \\
\text { Prezi }\end{array}$ & $\begin{array}{l}\text { The animation } \\
\text { prepared with } \\
\text { Powtoon }\end{array}$ & $\begin{array}{l}\text { The Pre-test } \\
\text { prepared with } \\
\text { Google Form }\end{array}$ \\
\hline & & $\begin{array}{l}\text { Poster } \\
\text { prepared } \\
\text { with Canva, }\end{array}$ & & $\begin{array}{l}\text { The } \\
\text { competition } \\
\text { prepared } \\
\text { with Scracht }\end{array}$ & $\begin{array}{l}\text { The electronic } \\
\text { cards prepared } \\
\text { with Quizlet }\end{array}$ \\
\hline & & & & & $\begin{array}{l}\text { The } \\
\text { competition } \\
\text { prepared with } \\
\text { Kahoot }\end{array}$ \\
\hline
\end{tabular}

At the end of the unit, a virtual museum was created with all activities prepared with the Artsteps application web 2.0 tools. An example lesson plan regarding the solid Pressure subject is given in Table 3 . 
Table3. Sample lesson plan

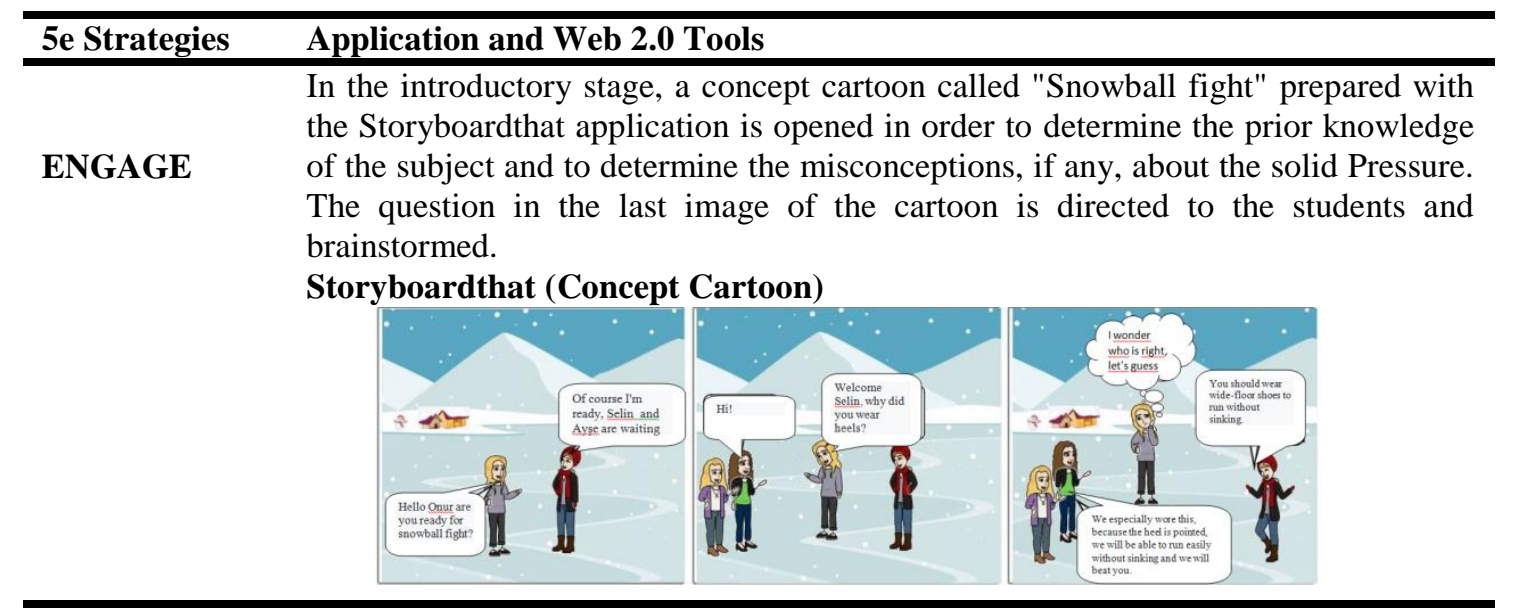

During the exploration stage, the concept story "Footprints on the Sand" prepared with Storybird is shown to the students. Questions are asked that will enable them to question which concepts related to the subject of the lesson are included in the story and what the variables are. Then, the questions at the end of the story are asked to be answered by the students. In addition, students are shown the poster called "Design Your Own Experiment" prepared with Canva. The students were asked to prepare an experiment in order to make predictions about the questions in the story. It was stated that the students could watch the sample experiment video by reading the Qr code on the poster with their mobile phones. The experiments designed by the students are examined.

EXPLORE

Storybird (Concept Story)

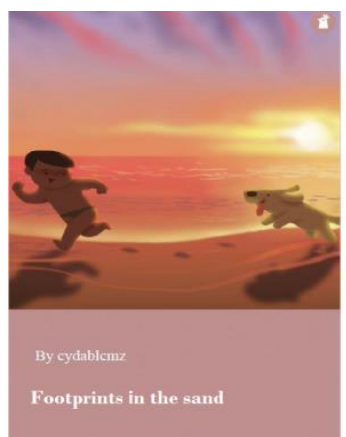

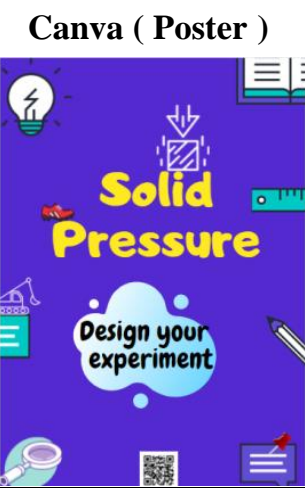

The "Solid Pressure Concept Map" prepared with Bubbl is opened for students to understand what the unit of solid Pressure is and the variables it depends on, and to eliminate possible misconceptions. Explanations are made on the concepts related to the subject with the students. Then, "We Examine Solid Pressure with Scientists" prepared with Powtoon. The animation called opens at 1:30 (Continued to be watched in elaborate stage). Animation is stopped in certain places and the lecture is carried out in detail to the students. Reference is made to the cartoons and concept stories used in the introduction and discovery stages.

EXPLAIN

Bubbl (Concept Map)

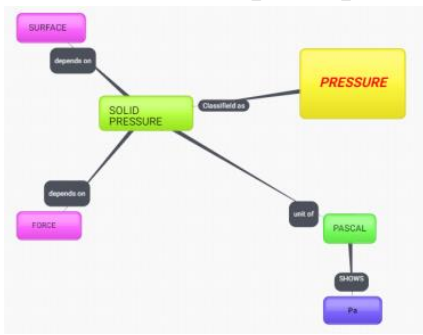

Powtoon (Animation)

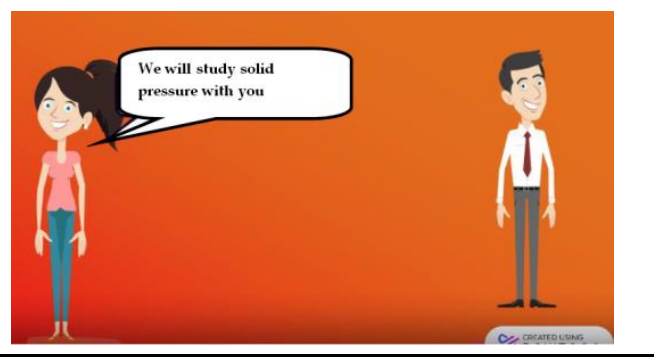


At this stage, "We Are Examining Solid Pressure With Scientists." The animation named "Solid Pressure Daily Life Examples" is opened to discuss with the students where solid Pressure is used in daily life and then, in order to develop the conceptual understanding and broad understanding of the students by associating the solid Pressure with daily life, starting from 1.30 minutes. Then, a game is opened in which students can test their answers to the question at the end of the prezi presentation from the "Scratch" application.

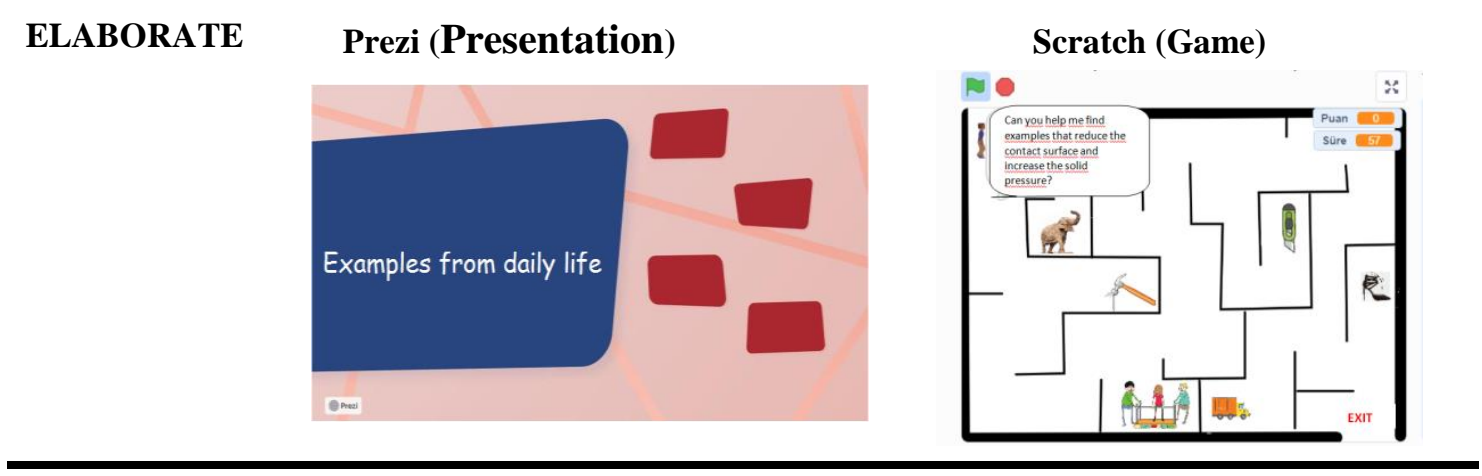

At this stage, students are asked to solve the questions in the Quizlet application in order to evaluate the subject and concepts. Then the Kahoot application is opened and an evaluation is made on the subject with the opened competition activity. Finally, the activity prepared in the Google Form application is given as homework. Note: At the end of the whole unit, a virtual museum has been created with the Artsteps application for all the activities prepared regarding the Pressure unit.

EVALUATE Artsteps (Museum)

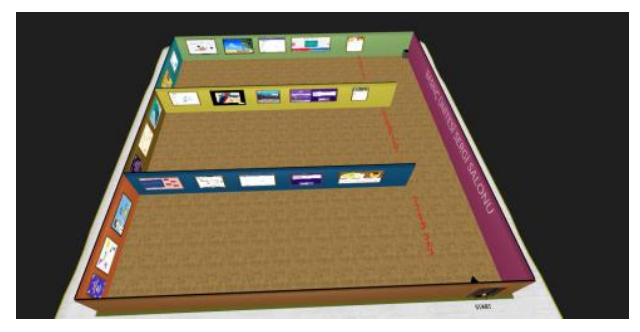

\section{Data collection Instruments}

\section{Academic achievement test}

In the study, the academic achievement test developed by Özcan, Koca and Söğüt (2019) was used to examine the academic achievements of the students regarding the Pressure unit. The achievement test has 20 multiple-choice questions concerning the Pressure unit gains. The KR-20 value of the achievement test was calculated as .83 by the researcher developed. Since this value is above .70, it can be said that the scale is reliable (Büyüköztürk, 2018). Necessary permissions were obtained for the use of the achievement test in the study, and the reliability analysis was performed and the Cronbach's Alpha reliability coefficient was .84.

\section{Structured interviews}

Interviews are the most preferred data collection method in qualitative research. Interviewing is the best way to reveal people's perceptions, interpretations, situation definitions and schemas in their minds (Punch, 2014). Structured interviews are a kind of interview in which questions prepared by the researcher in line with the purposes of the 
research are used (Y1ldırım \& Şimşek, 2013). An interview form was prepared by the researchers in order to prove the accuracy and representativeness of the results obtained from the achievement test and to determine the students' opinions about the activities and the science lesson. Questions of the interview were prepared by considering the sub-problems of the research on the interview form. The appropriateness of the questions in the interview form to the student level and sub-problems was examined by one expert in the field of science education and by five science teachers. Necessary arrangements have been made in line with the opinions and suggestions received, and there are 10 open-ended questions in the final form. Structured interviews were conducted with all experimental group students participating in the study. Ten questions in the interview form were delivered to all experimental group students at the same time via the Google Form application. Necessary analyses were made by collecting student answers.

\section{Data Analysis}

The analysis of the quantitative data obtained during the research was conducted by using the SPSS 24.0 package program and the analysis of the qualitative data was carried out by using the descriptive analysis method. In order to select the appropriate analysis methods, it was examined whether the data were normally distributed. Descriptive statistics results of the both groups of students' scores from the Pressure unit achievement test (mean of test scores $\left(\mathrm{X}^{\overline{)}}\right.$, standard deviation (S.s), Shapiro-Wilk normality test results regarding whether the scores show normal distribution are shown in Table 4.

Table4. Descriptive statistical results for the Pressure unit success test of both groups

\begin{tabular}{|c|c|c|c|c|c|c|}
\hline Data collection Instrument & Group & $\mathbf{N}$ & Test & $\overline{\boldsymbol{X}}$ & S.s & S-P (p) \\
\hline \multirow{4}{*}{ The Pressure Unit Achievement Test } & \multirow{2}{*}{ Experiment } & \multirow{2}{*}{21} & Pre test & 44,28 & 17,978 &, 127 \\
\hline & & & Post test & 73,09 & 19,485 & 322 \\
\hline & \multirow{2}{*}{ Control } & \multirow{2}{*}{20} & Pre test & 42,00 & 18,238 & ,089 \\
\hline & & & Post test & 61,75 & 13,645 & ,498 \\
\hline
\end{tabular}

When Table 4 was examined, it was determined that the Pressure unit achievement test scores of both groups showed normal distribution ( $p>, 05)$. Parametric analysis techniques were used in the study because of the normal distribution of the data. Independent sample t-test was conducted to determine whether the groups were similar to each other in terms of pre-tests. However, there was no statistically significant difference between the groups regarding pretests ( $p>.05$ ), single factor analysis of covariance (ANCOVA) was used to determine whether the experimental procedure was effective by eliminating the effects of the differences between the averages (Büyüköztürk, 2018). ANCOVA analysis enables the elimination of variables or variables related to the dependent variable, and external factors that cannot be controlled by the study design, by linear regression, apart from the factor or factors whose effect the experimental procedure is examined (Büyüköztürk, 2018). In addition, ANCOVA is a powerful statistic that can be used even under the condition that group mean scores are equal at the beginning, and it provides the real effect of the experimental process (Büyüköztürk, 2018). With this analysis, the achievement test pre-test scores of the both groups were determined as the covariate and the post-test scores as the dependent variable, and the effect on the post-test scores was examined.

Before analyzing the data, the conditions of ANCOVA analysis, the homogeneity of the variances, the linearity of the relationship between the dependent variable and the covariate, 
and the equality of the in-group regression coefficients (slopes) were checked. The homogeneity of the variances of the scores of the dependent variable of each group was examined with the Levene $\mathrm{F}$ test. The linearity between dependent variable and covariate was determined by Pearson Correlation analysis. The correlation coefficient being $70-1.00$ is a high level; $.70-.30$ is intermediate level;and a relationship between .30 and 00 was defined as a low-level relationship (Büyüköztürk, 2018). Equality of regression coefficients (slopes) within the group was determined by Pre-Test x Group common effect test. However, Bonferroni correction was examined in determining the difference between the groups according to the corrected averages.

The collected data in the qualitative dimension of the study were tabulated using descriptive analysis, one of the analysis techniques used in qualitative research. Descriptive analysis, the themes to be provided, and specific codes obtained in various data collection processes are summarized and explained. Data collected in this analysis are summarized and explained according to predefined codes and topics, and direct quotations from students are included in the presentation of the findings (Y1ldırım \& Şimşek, 2013). The responses in the applied form were coded in themselves and the answers suitable for this code were digitized and presented in the form of tables. While presenting student answers that are suitable for the codes, student names are coded as S1, T2. Digitizing qualitative data is important in increasing reliability, reducing bias, and giving the opportunity to compare codes emerging after analysis (Özdemir, 2010). The codes and frequencies of the responses of the students in the study group are given in the tables. In the rest of the tables, quotations are made from the student responses related to the questions.

\section{Findings}

Since the achievement test scores of the both groups' students provide a normal distribution (Table 4), the pre-test scores of both groups were analyzed using t-test analysis for independent samples. The results are given in Table 5.

Table5. The results of the t-test analysis

\begin{tabular}{|c|c|c|c|c|c|c|c|c|}
\hline $\begin{array}{l}\text { Data } \\
\text { Instrument }\end{array}$ & collection & Group & $\mathbf{N}$ & $\bar{X}$ & S.s & Sd & $\mathbf{t}$ & $\mathbf{p}$ \\
\hline \multirow{2}{*}{$\begin{array}{l}\text { The Pressure } \\
\text { Achievement test }\end{array}$} & \multirow{2}{*}{ Unit } & Experiment & 21 & 44,28 & 17,978 & \multirow{2}{*}{39} & \multirow{2}{*}{,- 404} & \multirow{2}{*}{,688 } \\
\hline & & Control & 20 & 42,00 & 18,238 & & & \\
\hline
\end{tabular}

As indicated in Table 5, it has been determined that there is no statistically significant difference between the groups as a result of the $t$ test for the independent samples made for the pre-test scores of the Pressure unit achievement test of the experiment and control group students in the study ( $p=, 688, p>, 05)$. This result shows that the scores of the achievement test of the experimental and control groups were equivalent before the application.

\section{Findings About the Pressure Unit The Achievement Tests}

The first sub-problem of the study was "Do the scores of the experiment students and the control students from the achievement test for the Pressure unit significantly vary?" was expressed. Before ANCOVA analysis to be made for this purpose, the assumptions required by the analysis were checked. Table 4 shows that the assumption of normality is suitable for ANCOVA analysis. The assumption of homogeneity of variances of the scores of the dependent variable of each group was investigated with the Levene $F$ test and it was 
determined that the variances were homogeneous $(\mathrm{F}(1.39)=2.902, \mathrm{p}=, 096, \mathrm{p}>$. Pearson Correlation analysis was performed in the assumption of linearity between the dependent variable and the covariate, and it showed that there was a moderate, positive and significant relationship between pre-test and post-test $(r=, 40, p=, 010, p<, 05)$. Since this relationship is greater than 30, it is sufficient to perform ANCOVA analysis (Büyüköztürk, 2018). As the last assumption of ANCOVA analysis, the results of the analysis of the joint effect test performed to test whether the pre-test $\mathrm{x}$ Group joint effect is significant on the posttest for equality of regression coefficients (slopes) are shown in Table 6.

Table6. Pretest for achievement test x group common impact test results

\begin{tabular}{llllll}
\hline Source of Variance & Sum of Squares & Sd & Mean of Squares & F & P \\
\hline Group &, 022 & 1 &, 022 &, 000 &, 992 \\
Pretest & 1715,986 & 1 & 1715,986 & 7,036 &, 012 \\
Group x pretest & 185,139 & 1 & 185,139 &, 759 &, 389 \\
Error & 9023,467 & 37 & 243,877 & & \\
Total & 199400,000 & 41 & & & \\
\hline
\end{tabular}

Table 6 shows that the Pretest x Group common effect on the posttest scores of the students is insignificant $(\mathrm{F} 1,37)=, 759, \mathrm{p}>, 05)$. This finding shows that the regression coefficients (slopes) calculated for the prediction of post-test scores depending on the achievement test pre-test scores of the both groups' students are equal. Valid ANCOVA interpretations can be made in the study on the verification of assumptions.

The average and standard deviation values of the pretest-posttest scores related to the achievement test of the students in the experimental and control groups and the posttest averages and standard error values calculated as a result of the covariance analysis and corrected with the Bonferroni test based on the multiple comparison test are given in Table 7.

Table7. Pre- and post-test mean scores in the achievement test and corrected post-test mean scores and standard deviations

\begin{tabular}{|c|c|c|c|c|c|c|}
\hline \multirow{2}{*}{ Groups } & \multirow{2}{*}{$\mathbf{N}$} & & \multicolumn{2}{|c|}{ Total Points } & \multicolumn{2}{|c|}{ Corrected Post-Test Mean Scores } \\
\hline & & & $\bar{X}$ & S.S & $\bar{X}$ & S.E \\
\hline \multirow{2}{*}{ Experiment } & \multirow{2}{*}{21} & Pre test & 44,28 & 17,978 & & \\
\hline & & Post test & 73,09 & 13,645 & 72,69 & 3,400 \\
\hline \multirow{2}{*}{ Control } & \multirow{2}{*}{20} & Pre test & 42,00 & 18,238 & & \\
\hline & & Post test & 61,75 & 13,645 & 62,18 & 3,485 \\
\hline
\end{tabular}

When Table 7 is examined, it is seen that the corrected post-test mean score $(\bar{X}=72.69)$ of the students in the experimental group is higher than the corrected post-test mean score $(\bar{X}=$ 62.18) of the students in the control group. Accordingly, it can be said that the academic achievement of the experiment students is higher than the control students. ANCOVA results regarding whether there is a significant difference between the achievement test-corrected posttest scores of the groups are given in Table 8. 
Table8. Results of the ANCOVA analysis about the corrected post-test scores of the groups

\begin{tabular}{llllll}
\hline Source & Sum of Squares & df & Mean Square & F & Sig. \\
\hline Pre test(regression) & 1728,953 & 1 & 1728,953 & 7,135 &, 011 \\
Groups (experiment/control) & 1125,682 & 1 & 1125,682 & 4,645 &, $\mathbf{0 3 8}^{*}$ \\
Error & 9208,606 & 38 & 242,332 & & \\
Total & 199400,000 & 41 & & & \\
Corrected Total & 12256,098 & 40 & & & \\
\hline
\end{tabular}

When Table 8 is examined, when the pre-test scores of the groups controlled according to the ANCOVA results, a significant difference was found between the corrected post-test mean scores of the groups in favor of the group in which the activities were used $(F(1,38)=4,645$, $\mathrm{p}<, 05)$.

\section{Findings regarding the opinions of the experimental group students}

The data related to the second sub-problem of the study were collected through structured interviews in order to determine the students' opinions about the activities of the students in the experimental group, in which the activities created with Web 2.0 tools were applied. The answers given to the questions in the interview form were divided into categories and coded. In addition, these codes are classified as positive and negative attitudes towards activities developed with Web 2.0 tools. The codes are presented in the table below. While presenting student answers in accordance with the codes, the names of the students were specified as S1, S2.

Students' answers to the first question in the interview form viz. "In your opinion, what are the features that distinguish the activities in the Pressure unit from the activities in other units?" expressed in the form are given in Table 9 below.

Table9. The answers to the first question in interview form

\begin{tabular}{llc}
\hline Answers & $\begin{array}{c}\text { Positive } \\
\text { Opinion }\end{array}$ & $\begin{array}{c}\text { Negative } \\
\text { Opinion }\end{array}$ \\
\hline Categories of answers & f & f \\
\hline Associating with daily life & 3 & - \\
Seeing as a hands-on activity & 3 & - \\
Finding activities fun & 7 & - \\
Qualifying as instructive & 5 & - \\
Seeing that activities were difficult & - & 2 \\
Could not see the difference & - & 1 \\
\hline Total & $\mathbf{1 8}$ & $\mathbf{3}$
\end{tabular}

According to Table 9, it was determined that 18 students had a positive opinion about the activities in the Pressure unit. The students with positive views stated that the activities in the Pressure unit differed from the activities in the other units as more fun and instructive. However, it was determined that the views of 3 students about the activities in the Pressure unit were negative. Students with negative views stated that the activities were difficult and they could not see the difference with the other units. The answers to the first question according to the codes are given below:

S1: ' It is easier to understand because it has examples from daily life "'

S2:" It was a more effective learning because the application was used in many activities", 
S15: " to me, it's more fun. Because I do science with fun and love"

S5: "Reinforce and learn the subject with activities/ stories."

S20: "Since it is more comprehensive and difficult than others "

S14: " not too long"

"Have the students been interested in the activities related to the Pressure unit during the distance education process? What are the reasons for your answer?" The answers they gave concerning the second question in the form expressed in the form of the following are given in Table 10.

Table10. The answers to the second question in interview form

\begin{tabular}{lll}
\hline Answers & Interesting & Not Interesting \\
\hline Categories of answers & $\mathbf{f}$ & $\mathbf{f}$ \\
\hline Gameful and fun & 6 & - \\
Activity that encourages learning & 11 & - \\
Seeing the development immediately & 3 & - \\
Visuality & 1 & - \\
\hline Total & $\mathbf{2 1}$ & $\mathbf{0}$
\end{tabular}

Table 10 indicated that all students had the view that the activities in the Pressure unit were interesting. It was determined that the reasons for the activities to attract attention were found to be more encouraging to learning. No opinion was given that the activities were not of interest. Following are the answers to the second question according to the codes of the students:

\section{S1: "Some of them are like games and I am more interested"}

S11:"It was all very instructive and amusing. I learned better"

S6: "It's better in test form. Personally, I develop myself by solving questions. It also gets better like this. We can see our mistakes immediately and improve ourselves"

\section{S7: "They give information visually"}

Answers to "Which of the Web 2.0 tools used in the activities related to the Pressure unit during the distance education process attracted the most attention? What are the reasons for your answer? given are shared in Table 11 below.

Table11. The answers to the third question in interview form

\begin{tabular}{lll}
\hline Answers & Interested & $\begin{array}{l}\text { Not } \\
\text { Interested }\end{array}$ \\
\hline Categories of answers & f & f \\
\hline Kahoot & 12 & - \\
Google Form & 14 & - \\
Scratch & 8 & - \\
Quizlet & 3 & - \\
Storybird & 1 & - \\
\hline Total & $\mathbf{3 8}$ & $\mathbf{0}$
\end{tabular}


Table 11 indicated that students stated that they found most interesting Google Form (14 students), Kahoot (12 students) and Scratch (8 students). They justified the reason why Web 2.0 tools attract attention as interacting more. Web 2.0 did not comment that the tools were not of interest. The appropriate answers from the students' opinions to the third question are given below:

S4: "There is a competitive environment and this is more motivating."

S3 : "As Kahoot is a game, you can race with your friends."

S9: "As we can make a quiz show in Kahoot and you can play game in Scratch."

S20 : "It enabled us to apply what we learned and to see and learn from different angles."

Answers to: Which of the Web 2.0 tools you would like to use during the course by designing yourself? Why is that?" are given in Table 12.

Table12. The answers to the fourth question in interview form

\begin{tabular}{lll}
\hline Answers & Interested & $\begin{array}{l}\text { Not } \\
\text { Interested }\end{array}$ \\
\hline Categories of answers & $\mathbf{f}$ & $\mathbf{f}$ \\
\hline Preparing a competition / test & - \\
Preparing a game & 4 & - \\
I don't think to design & - & 2 \\
\hline Total & $\mathbf{1 9}$ & $\mathbf{2}$
\end{tabular}

It is clear from Table 12 that 19 students had a willingness to design using Web 2.0 tools used in developing activities. They justified their reason for using Web 2.0 tools as preparing a competition / test. However, it was determined that 2 students had negative opinions about using Web 2.0 tools. The answers to the fourth question according to the codes are given below:

S4 : "I would love to use the Kahoot application. Because there was a competitive environment, competition in it. This allows students to work more ambitiously."

S9: "Scratch, because I think learning with games is more catchy."

S5 : "I do not want to design."

Answers to: "How do you think the activities (cartoon, kahoot etc.) created with Web 2.0 tools in the distance education process affected the understanding of the subject in the teaching of the science lesson?" are given in Table 13 below.

Table13. The answers to the fifth question in interview form

\begin{tabular}{llc}
\hline Answers & $\begin{array}{l}\text { Positive } \\
\text { effect }\end{array}$ & $\begin{array}{c}\text { Negative } \\
\text { effect }\end{array}$ \\
\hline Categories of answers & f & f \\
\hline Memorable & 11 & - \\
Fast learning & 5 & - \\
Motivating & 5 & - \\
\hline Total & 21 & $\mathbf{0}$
\end{tabular}


Table 13 indicated that all students think that the science lesson of activities created with Web 2.0 tools has a positive effect on understanding the subject. Students with positive views justified the teaching of Science lesson of activities created with Web 2.0 tools on the fact that the subjects were more memorable. There was no negative opinion from the students that the activities created using Web 2.0 tools had no effect on the teaching of Science. The answers to the fifth question according to the codes are given below:

\section{S2: "It helped the subject to be memorable and effective."}

S7 : "It contributed to the understanding and learning more quickly."

S4: "I understood the subjects better. Because it is fun, it makes you want to study more."

Answeres to the question: "Did you have difficulty in reaching the activities (Scratch, Google form, Kahoot etc.) created with Web 2.0 tools with the devices you use in distance education?" are given in Table 14 below.

Table14. The answers to the sixth question in interview form

\begin{tabular}{lll}
\hline Answers & $\begin{array}{c}\text { Positive } \\
\text { Opinion }\end{array}$ & $\begin{array}{c}\text { Negative } \\
\text { Opinion }\end{array}$ \\
\hline Categories of answers & f & f \\
\hline I had no difficulty & 19 & - \\
I had difficulty & - & 2 \\
\hline Total & $\mathbf{1 9}$ & $\mathbf{2}$
\end{tabular}

According to the findings in Table 14, 19 students were of the opinion that they did not have any difficulties in reaching the activities created with Web 2.0 tools with the devices they used. However, 2 students stated that they experienced difficulties. Students who had a negative view justified their difficulties in accessing the activities created with Web 2.0 tools on their technological infrastructure systems and their own forgetfulness. The answers to the sixth question according to the codes are given below:

S17: "Although we completed the activities and tests you sent us via web 2.0 tools, we could not send them back to you because the system failed, but in such a difficult period, we can only receive training online."

S11 :"I couldn't enter the platform because I forgot the time when the activity in the Scratch application will be held, but I used scratch before."

Answers given to: "Has there been any change in your interest in the course of teaching Science lessons in the distance education process with activities created with Web 2.0 tools? If so, how did it change?" are given in Table 15 below.

Table15. The answers to the seventh question in interview form

\begin{tabular}{lcc}
\hline Answers & $\begin{array}{c}\text { Positive } \\
\text { Opinion }\end{array}$ & $\begin{array}{c}\text { Negative } \\
\text { Opinion }\end{array}$ \\
\hline Categories of answers & f & $\mathbf{f}$ \\
\hline I had no difficulty & 15 & - \\
I had difficulty & - & 6 \\
\hline Total & $\mathbf{1 5}$ & $\mathbf{6}$
\end{tabular}


Table 15 indicated that 15 students had a positive opinion about the change in their interest towards the lesson when science lessons are taught with activities created with Web 2.0 tools. However, it was determined that 6 students stated that there was no change in their interests. Students with negative views justified the reason for the lack of change in their interests as their interest in science was always at the highest level. The answers to the seventh question according to the codes are given below:

S5 : "I love the lesson so it has not changed much."

S13 : "I was most interested in the Science lesson, and the activities created with Web 2.0 tools did not change my interest in the lesson."

With the transition to face-to-face education, would you like the activities created with Web 2.0 tools to be used in Science lessons again? Why is that?" The answers they gave to this eighth question in the interview form expressed in the form of answers are given in Table 16 below.

Table16. The answers to the eighth question in interview form

\begin{tabular}{lll}
\hline Answers & $\begin{array}{c}\text { Positive } \\
\text { Opinion }\end{array}$ & $\begin{array}{l}\text { Negative } \\
\text { Opinion }\end{array}$ \\
\hline Categories of answers & f & f \\
\hline Positive contribution to class attendance & 7 & - \\
It's easy to learn and memorable & 9 & - \\
It's fun & 5 & - \\
\hline Total & $\mathbf{2 1}$ & $\mathbf{0}$
\end{tabular}

Table 16 indicated that all students think positively about the use of the activities created with Web 2.0 applications in Science lessons with the transition to face-to-face education. The students with positive views justified that the activities created with Web 2.0 tools are materials that facilitate learning in face to face education. The answers to the eighth question according to the codes are given below:

S15: "Yes, because it made me attend the lesson more effectively. With cartoons, the lesson is better for me."

S19: "Yes I would like it to be used. Because Science lesson is visually better stored in mind, it is useful to make these applications."

S9: "Yes, I would like to use it, because it is fun."

Answers to: "Would you like the activities created with Web 2.0 tools to be used in other units?" are given in Table 17 below.

Table17. The answers to the ninth question in interview form

\begin{tabular}{lll}
\hline Answers & $\begin{array}{c}\text { Positive } \\
\text { Opinion }\end{array}$ & $\begin{array}{c}\text { Negative } \\
\text { Opinion }\end{array}$ \\
\hline Categories of answers & $\mathbf{f}$ & $\mathbf{f}$ \\
\hline Yes, I would & 21 & - \\
No, I wouldn't & - & $\mathbf{0}$
\end{tabular}


It is clear from Table 17 all students had a positive view of using the activities created with Web 2.0 tools in other units. The answers to the opinions of the students regarding the ninth question are given below:

S17:" Yes because it can make other units as enjoyable as Pressure unit and we students' interest in the lessons may increase."

S15:"Yes. Because it may cause me to participate more effectively in other units. Cartoons have always attracted my attention and I started to listen more carefully."

Answers to: "In which lessons do you want the activities created with Web 2.0 tools to be used in other lessons other than Science?" are given in Table 18 below.

Table18. The answers to the tenth question in interview form

\begin{tabular}{lcl}
\hline Answers & $\begin{array}{c}\text { Positive } \\
\text { Opinion }\end{array}$ & $\begin{array}{l}\text { Negative } \\
\text { Opinion }\end{array}$ \\
\hline Categories of answers & $\mathbf{f}$ & $\mathbf{f}$ \\
\hline Mathematics & 11 & - \\
Turkish & 11 & - \\
English & 12 & - \\
History of Revolution and Kemalism & 12 & - \\
Religious Culture and Moral Knowledge & 1 & - \\
I wouldn't want to use Web 2.0 tools in other lessons & - & 1 \\
\hline Total & $\mathbf{4 7}$ & $\mathbf{1}$
\end{tabular}

According to the findings in Table 18, 11 of the students are Mathematics, 11 of them are Turkish, 12 of them are English, 12 of them are Turkish. It has been determined that they have a positive opinion on the use of activities created with Web 2.0 tools in the History of Revolution and Kemalism and 1 of them in Religious Culture and Moral Knowledge courses. On the other hand, it was determined that 1 student expressed an opinion on not using Web2.0 tools in activities in other lessons. The answers to the students' opinions regarding the tenth question are given below:

\section{S5:"There is no need to use it in other lessons."}

S15:" I think it can be used in all classes."

\section{Discussion and Conclusion}

Within the scope of the study, it was examined whether the activities created using Web 2.0 tools in accordance with the 5E model in teaching the Pressure unit to 8th grade students in distance education had a significant effect on students' success. According to the analysis, it was determined that there is a significant difference in favor of the experiment group between the post-test average success scores corrected according to the pre-test scores. This situation shows that the study group in which the activities were used was more successful than the other group at the end of the teaching process. Accordingly, it can be said that the activities created with Web 2.0 tools in accordance with the 5E model are more effective in increasing student success in distance education compared to the activities carried out on the basis of the Science course curriculum. In their experimental study, they determined that the use of Web 2.0 tools in physics teaching made a significant difference in student achievement. Similarly, Özdem Köse (2019) reached the conclusion in her study that 
the argumentation activities she developed using Web 2.0 tools in teaching the Force and Energy unit made a significant difference in student achievement (Baig, 2011). In their study, Mete and Batibay (2019) determined that the use of Kahoot, one of the web 2.0 applications, made a significant difference in student achievement. Korucu (2020) determined in his study that digital stories created with Web 2.0 tools in science education made a significant difference in student achievement. In his experimental study, Gürleroğlu (2019) concluded that the activities created with Web 2.0 applications in accordance with the 5E model in science education made a significant difference in student achievement. In their study, Özenç, Dursun, and Şahin (2020) conducted the lesson in the experiment 1 group with the activities built with Web 2.0 applications suitable for the $5 \mathrm{E}$ model, the activities built with Web 2.0 tools in the experiment 2 group, and the activities in the curriculum in the control group. According to result of their research, they determined that there is a significant difference between the groups in favor of the experiment 1 and experiment 2 groups in student achievement. In other words, they determined that the activities created with Web 2.0 tools suitable for the 5E model and the activities developed with Web 2.0 tools made a significant difference in student success. However, while experiment 1 and experiment 2 groups did not find a significant difference in student achievement, they noted that the mean posttest success score was higher in the experiment 1 group. Balliel Ünal (2017) reached the conclusion that web-based learning in distance education made a significant difference in student achievement in the item exchange unit. These researches show that activities created with Web 2.0 tools suitable for $5 \mathrm{E}$ model in distance education have a positive effect on student achievement. It is seen that the findings of the studies in the literature are in harmony with the result of this study.

Qualitative data of this study were collected with a structured interview form consisting of 10 questions with all students whom the prepared activities were applied.

In the interview form, the students were asked about the activities developed with Web 2.0 tools, about the Web 2.0 tools used to develop activities, and about the continuity of the applications using such tools. The findings in the interview form show that the students associated the activities developed using Web 2.0 tools with daily life more than other units. They also reported that the activities were fun, practice-based and more instructive. These opinions show that web 2.0 tools provide learning by doing and support the constructivist approach. In other studies on this subject, it was found that the activities produced by Web 2.0 tools are fun, instructive and motivating (Williams \& Chinn, 2009; Özkan, 2010; Çetin, 2010; Weller, 2013; Akgündüz, 2013; Karahan \& Roehrig; 2016; Gündoğdu and Korucu, 2018; Sar1 2019; Gürleroğlu 2019; Bünül, 2019; Usta, 2020). This research has revealed that the activities carried out using Web 2.0 tools used in face-to-face education are effective and efficient in distance education as well.

In the interview questions, students' opinions about the web 2.0 tools indicated that the web 2.0 tools used in the activities in the lessons made the subjects more memorable, showed the development instantly, enriched the course content and made it fun, and gave instant feedback to evaluate the subjects. In addition, they emphasized that these applications are an important reinforcement tool. It has been demonstrated in other studies that such factors increase interest and motivation towards the course (Küçük, Kapkin, \& Göktaş 2015, Kaynar, 2019). Those who said that the interest in the course did not increase stated that their interest in science lessons was already high, so there was no increase. Therefore, it can be said that even those who give negative answers like these applications. In the responses of the students to using web 2.0 tools, they wanted to make their own designs by using web 2.0 tools such as Scratch, 
Kahoot and Google Form that should solve questions and get points (Mete \& Batibay, 2019; Gürleroğlu 2019; Saraçoğlu 2019). They said that the reason for choosing these applications is that they resemble a game and offer a competition environment with their friends. It was concluded that the use of these tools in virtual classroom environments in distance education increased students' interest in the course and their desire to use web 2.0 tools (Hartshorne \& Ajjan, 2009; Gray, Thompson, Sheard, Clerehan, \& Hamilton, 2010; Hoic-Bozic, Holenko Dlab, \& Mornar, 2016). Recent studies show that Web 2.0 technologies also affect learning and performance (Smith, Salaway, \& Caruso, 2009; Solomon \& Schrum, 2007).

In the last part of the interview questions, the students were asked questions about the continued use of Web 2.0 applications in other units of the science course, in other courses and in face-to-face education. These questions, as in other studies (Sendall, Ceccucci and Peslak, 2008; Mete \& Batıbay, 2019) generally it would be beneficial to use web 2.0 tools and they stated that it should continue. Web 2.0 tools are perhaps becoming an indispensable element for enriching the course in the distance education process. At the same time, it was stated that these applications improve group work, effective learning, thinking and problem solving skills, and offer students appropriate content (Chunyan Haitao \& Guolin, 2014; Karaman, Yildirım, \& Kaban, 2008). It shows that for an environment in which students are actively involved in the learning process, web 2.0 tools must be fully integrated with active teaching and learning methods (Zhao et al., 2010).

As a result, it is found that the activities created with web 2.0 tools in accordance with the $5 \mathrm{E}$ model in teaching eighth-grade students to the Pressure unit in distance education have a positive effect on student achievement and views.

\section{Recommendations}

In line with the results obtained from the study, suggestions for researchers who want to study in this field are included.

(1) This study was carried out within the scope of the Pressure unit. In other science subjects, the effectiveness of the activities created with Web 2.0 tools suitable for the $5 \mathrm{E}$ model can be investigated.

(2) The study can be carried out at different grade levels and in different lessons.

(3) The effect of students' studies using Web 2.0 tools on student achievement and opinion can be examined.

(4) The effect of using Web 2.0 tools with other learning models on success can be examined.

(5) A case study on the possible reasons for students' negative views and attitudes towards Web 2.0 tools can be suggested.

\section{Note}

This paper was presented as an oral presentation at 3rd International Eurasian Educational Research Congress (EJER 2021) held in Aksaray (Turkey) on July 7-10, 2021. 


\section{References}

Ajjan, H., \& Hartshorne, R. (2008). Investigating faculty decisions to adopt web 2.0 technologies: theory and empirical tests. The Internet and Higher Education, 11(2), 71-80.doi:10.1016/j.iheduc.2008.05.002

Aktaş, M. (2013). Fen ve teknoloji dersinde uzaktan eğitimin öğrencilerin akademik başart ve tutumlarl üzerindeki etkisi [The effect of web-based distance education on academic success and attitudes of students in science and technology lesson]. (Unpublished Master's Thesis). Bülent Ecevit University, Institute of Social Sciences, Zonguldak.

Alpar, D., Batdal, G., \& Avc1, Y. (2007). Öğrenci merkezli eğitimde eğitim teknolojileri uygulamaları [Educational technologies in student-centered education applications]. Hasan Ali Yücel Journal of the Faculty of Education, 7 (1), 9-31. Retrieved from https://dergipark.org.tr/tr/pub/iuhayefd/issue/8786/109853.

Altun, A. (2008). Yapılandırmacı Öğretim Sürecinde Wiki Kullanımı [Using wiki in constructivist teaching process]. In International Educational Technology Conference (IETC), Eskişehir, Türkiye.

Aytan, T., \& Başal, A. (2015). Türkçe Öğretmen Adaylarının Web 2.0 Araçlarına Yönelik Algılarının İncelenmesi [Investigation of the perceptions of pre-service Turkish teachers towards web 2.0 tools]. Turkish Studies (Electronic), 10 (7), 149-166. DOI: $10.7827 /$ TurkishStudies.8388

Bakioğlu, B., \& Çevik, M. (2020). COVID-19 Pandemisi Sürecinde Fen Bilimleri Öğretmenlerinin Uzaktan Eğitime İlişkin Görüşleri [Science teachers' views on distance education in the covid-19 pandemic process]. Turkish Studies, 15(4), 109129. https://dx.doi.org/10.7827/TurkishStudies.43502

Baig, M. A. (2011). A critical study of effectiveness of online learning on students' achivments. I-manager's Journal of Educational Technology, 7(4).

Ballıel Ünal, B. (2017). Web Tabanlı Uzaktan Eğitimin Fen Bilimleri Konularında Öğrenci Başarısına Etkisi [Effect of web-based distance education on student achievement in science education]. International Journal of Turkish Educational Sciences, 5(9), 481490. Retrieved from https://dergipark.org.tr/tr/pub/goputeb/issue/34356/381085

Benzer, A. (2017). Dijital çă̆da ögretim teknolojileri ile türkçe eğitim [Turkish education with instructional technologies in the digital age]. Ankara:TTGV.

Bolatl1, Z., \& Korucu, A. (2018). Secondary school students' feedback on course processing and collaborative learning with web 2.0 tools-supported stem activities. Bartın University Journal of Faculty of Education, 7 (2) , 456-478.

Bugawa, A. M., \& Mirzal, A. (2017). The impact of web 2.0 technologies on the learning experience of students in higher education: a review. International Journal of WebBased Learning and Teaching Technologies, 13( 3), 1-17.

Bünül, R. (2019). Fen alanları öğretmen adaylarının web 2.0 araçlarının öğretimde kullanımına ilişkin görüsleri [The views of preservice science teachers about the use of web 2.0 tools in teaching]. (Unpublished Master's Thesis). Dicle University, Institute of Educational Sciences, Diyarbakır.

Büyüköztürk, Ş. (2018). Sosyal bilimler için veri analizi el kitabı: istatistik, araştırma deseni, spss uygulamalarl ve yorum[Data analysis handbook for social sciences: statistics, research design, spss applications and interpretation]. Ankara: Pegem Academy Publ.

Büyüköztürk, Ş., Kılıç-Çakmak, E., Akgün, Ö.E., Karadeniz, Ş., \& Demirel, F. (2019). Bilimsel araştırma yöntemleri[Scientific research methods. $\left(26^{\text {th }}\right.$ edition), Ankara: Pegem Publ.

Bybee, R.W. (2014). The bscs 5e instructional model: personal reflections and contemporary implications. Guest Editorial,10-13. 
Chunyan, L., Haitao, C., \& Guolin, L. (2014). The effect of web2.0 on learning management system. International Journal of Multimedia and Ubiquitous Engineering, 9 (10), 6778.

Creswell, J. H. (2017). Karma Yöntem Araştırmalarına Giriş[Introduction to Mixed Method Research]. (Trant, Mustafa Sözbilir.). Ankara: Pegem Academy.

Çalışkan, S., Güney, Z., Sakhieva, R. G., Vasbieva, D. G., \& Zaitseva, N. A. (2019). Teachers' views on the availability of web 2.0 tools in education. International Journal of Emerging Technologies in Learning (IJET), 14(22): 70-81.

Elmas, R., \& Geban, Ö. (2012). Web 2.0 tools for 21 st century teachers. International Online Journal of Educational Sciences, 4(1), s.243-254.

Eze, E. M. (2016). Awareness and use of web 2.0 tools by LIS students at university of Nigeria, Nsukka, Enugu State, Nigeria. Library Philosophy \& Practice (e-journal). Retrieved from: http://digitalcommons.unl.edu/libphilprac/1355.

Gray, K., Thompson, C., Sheard, J., Clerehan, R., \& Hamilton, M. (2010). Students as web 2.0 authors: implications for assessment design and conduct. Australasian Journal of Educational Technology, 26 (1), 105-121.

Gülnar, M.,\&Acar, S. (2018). Bilgisayar ve öğretim teknolojileri eğitimi bölümü öğrencilerinin bilgi okuryazarlı̆̆ durumlarına göre incelenmesi [An investigation of ict students' information literacy self-efficacy perceptions according to their web 2.0 technology use]. Journal of the National Academy of Education, 2(1), 54-65.Retrieved from https://dergipark.org.tr/tr/pub/uead/issue/36657/397337.

Gündoğdu, M. M., \& Korucu, A. T. (2018). Ağ Günlükleri Teknolojisi ile Geliştirilmiş İşbirlikli Öğrenme Ortamının Ortaokul Öğrencilerinin Akademik Başarıları İle Problem Çözmeye Yönelik Yansitıcı Düşünme Becerilerine Ve Motivasyon Düzeylerine Etkisi [The Effects of Collaborative Learning Developed with Blog Technology on Reflecting Thinking Skills Towards Problem Solving and Motivation Levels and on Academic Success of Secondary School Students]. Anadolu University Journal of Education Faculty, 2(3), 196-226.

Gürleroğlu, L. (2019). 5e modeline uygun web 2.0 uygulamalart ile gerçekleştirilen fen bilimleri ögretiminin ögrenci başarısına motivasyonuna tutumuna ve dijital okuryazarlı̆̆ına etkisinin incelenmesi [Examination of the effect of science teaching conducted with web 2.0 applications in accordance with the 5e model on student achievement motivation, attitude and digital literacy].(Unpublished Master's Thesis).Marmara University, Institute of Educational Sciences, İstanbul.

Hartshorne, R., \& Ajjan, H. (2009). Examining student decisions to adopt web 2.0 technologies: theory and empirical tests. Journal of Computer High Education, 21, 183-198 https://doi.org/10.1007/s12528-009-9023-6

Hoic-Bozic, N., Holenko Dlab, M., \& Mornar, V. (2016). Recommender system and web 2.0 tools to enhance a blended learning model. IEEE Transactions on Education, 59(1), $39-44$.

Horzum, M. B. (2010). Öğretmenlerin web 2.0 araçlarından haberdarlığı, kullanım sıklıkları ve amaçlarının çeşitli değişkenler açısından incelenmesi [Investigating teachers' Web 2.0 tools awareness, frequency and purposes of usage in terms of different variables]. International Journal of Human Sciences,7(1). Retrieved from: https://www.acarindex.com/dosyalar/makale/acarindex-1423936655.pdf

Karaman, S., Yildırım, S., \& Kaban, A. (2008, December). Web 2.0 Uygulamalarının Eğitimde Kullanımına İlişkin Araştırmalar ve Sonuçları [Research and results on the use of web 2.0 applications in education]. XIII. In Turkey Internet Conference Proceedings, 35-40. Ankara Turkey. 
Kaynar, T. (2019). Web 2.0 Araçlarının yabancı dil ögretiminde kullanımı [The use of Web 2.0 Tools in foreign language teaching].(Unpublished Master's Thesis).Marmara University, Institute of Educational Sciences, İstanbul.

Küçük, S., Kapakin, S., \& Göktaş, Y. (2015). Tıp Fakültesi Öğrencilerinin Mobil Artırılmış Gerçeklikle Anatomi Öğrenimine Yönelik Görüşleri. [Medical faculty students' views on anatomy learning via mobile augmented reality technology]. Journal of Higher Education \& Science / Journal of Higher Education and Science, 5 (3) 316-323.

Kutlu Demir, Ö. (2018). 21st century learning: intergation of web 2.0 tools in turkish adult language classrooms. (Unpublished doctoral dissertation), Çukurova University Institute of Social Sciences, Adana.

Korucu, A . (2020). Fen Eğitiminde Kullanılan Dijital Hikâyelerin Öğretmen Adaylarının Akademik Başarısı, Sayısal Yetkinlik Durumları ve Sorgulama Becerileri Üzerindeki Etkisi [The effect of digital stories used in science education on academic achievement, digital empowerment and inquiry skills of teacher candidates]. Journal of Kastamonu Education,28 (1),352-370. DOI: 10.24106/kefdergi.3617

Liu, T. C., Peng, H., Wu, W. H., \& Lin, M. S. (2009). the effects of mobile natural science learning based on the 5e learning cycle: a case study. Educational Technology \& Society, 12(4), 344-358.

Lu, J., Lai, M., \& Law, N. (2010). Knowledge building in society 2.0: challenges and opportunities. In M. S. Khine \& I. M. Saleh (Eds) New science of learning: Computers, cognition and collaboration in Education (pp. 553-567). Newyork, Springer.

Martin, D. J. (2012). Elementary science methods: a constructivist approach. (6th Edition). Belmont, CA: Wadsworth/Thomason Learning.

Mete, F., \& Batıbay, E. F. (2019). Web 2.0 uygulamalarının Türkçe eğitiminde motivasyona etkisi: Kahoot örneği [The impact of web 2.0 applications on motivation in the Turkish course: the kahoot example]. Journal of Mother Language Education, 7(4), 1029-1047.

Milli Eğitim Bakanlığı.( 2017). Fen Bilimleri Dersi Öğretim Programı (ilkokul Ve Ortaokul 3, 4, 5, 6, 7 ve 8. Siniflar)[Science Course Curriculum (Primary School and Secondary School 3, 4, 5, 6, 7 and 8. Grades). Ankara: State Books Printing House.

O'Reilly, T. (2005). What is web 2.0 ? Design patterns and business models for the next generation of software. Retrieved from: https://www.oreilly.com/pub/a/web2/archive/what-isweb-20.html?page=1

OECD (2019). Education at a glance database. Retrieved from https://www.oecd.org/education/education-at-a-glance/ EAG2019_CN_NLD.pdf

Özcan, H., Koca, E., \& Söğüt, M. (2019). Ortaokul öğrencilerinin basınç kavramıyla ilgili anlayışlarını ölçmeye yönelik bir test geliştirme çalışması [Development of an instrument for measuring secondary school students' understanding of Pressure]. Journal of Research in Education and Society, 6(1), 130-144.

Özçınar, Z., Sakhieva, R. G., Pozharskaya, L. E., Popova., V. O., \& Melnik, V. M. (2020). Student's perception of web 2.0 tools and educational applications. International Journal of Emerging Technologies in Learning (iJET), 15(23):220-233.

Özdem Köse, Ö. (2019). Teknoloji destekli argümantasyon uygulamalarının 7. sinıf ögrencilerinin akademik başarılarına, kavramsal anlamalarına ve tutumlarına etkisi: kuvvet ve enerji [The effect of technology-supported argumentation applications on 7 th grade students' academic achievement, conceptual understanding and attitudes: force and energy]. (Unpublished Master's Thesis). Marmara University, Institute of Educational Sciences, İstanbul. 
Özdemir, M. (2010). Nitel Veri Analizi: Sosyal Bilimlerde Yöntembilim Sorunsalı Üzerine Bir Çalışma [Qualitative data analysis: a study on methodology problem in social sciences]. Eskişehir Osmangazi University Journal of Social Sciences, 11 (1) , 323343.

Özenç, M., Dursun, H., \& Şahï, S. (2020). The effect of activities developed with web 2.0 tools based on the 5e learning cycle model on the multiplication achievement of 4th graders . Participatory Educational Research , 7 (3), 105-123.

Pamuk, S., Ülken, A., \& Dilek, N. (2013). Öğretmen Adaylarının Öğretimde Teknoloji Kullanım Yeterliliklerinin Teknolojik Pedagojik İçerik Bilgisi Kuramsal Perspektifinden İncelenmesi [The investigation of preservice teachers' technology integration competencies from technological pedagogical content knowledge framework]. Mustafa Kemal University Journal of Social Sciences Institute, 9 (17), 415-438.

Punch, K. F. (2014). Introduction to social research: quantitative and qualitative approaches, Third Edition, SAGE.

Pürbudak, A. (2020). Web 2.0 temelli işbirlikli grup etkinliklerinin ögrrenme stilleri bağlaminda deneysel olarak incelenmesi [Experimental investigation of web 2.0 based collaborative group activities in the context of learning styles]. (Unpublished Master's Thesis). Necmettin Erbakan University, Institute of Educational Sciences, Konya.

Saraç, H. (2017). Öğrenme Modelinin Öğrenme Ürünlerine Etkisi: Meta-analiz Çalışması [5e Öğrenme Modeli Kullanımının Öğrencilerin Öğrenme Çıktılarına Etkisi [The effect of 5e learning model usage on students' learning outcomes: meta-analysis study]. Unlimited Education and Research Journal, 2 (2), 16 - 4.

Saraçoğlu, G. K. (2019). Lise Öğrenci ve Öğretmenlerinin Kahoot Kullanımına İlişkin Görüşleri [Views of high school students and teachers on kahoot use]. Mediterranean Journal of Educational Research, 13(29), 1-19.

Sarı, E. (2019). Web 2.0 uygulamalarına göre tasarlanmış fen bilimleri dersinin etkililiğinin incelenmesi [Examination of the effectiveness of the science course designed according to Web 2.0 applications]. (Unpublished master's thesis). Düzce University Institute of Educational Sciences, Düzce.

Sendall, P., Ceccucci, W., \& Peslak, A. (2008). Web 2.0 matters: an analysis of implementing web 2.0 in the classroom. Information Systems Education Journal, 6(64).

Solomon, G., \& Schrum, L. (2007). Web 2.0: new tools, new schools. International Society for Technology in Education, Washington.

Smith, S. D., Salaway, G., \& Caruso, J. B. (2009). The ecar study of undergraduate students and information technology. EDUCAUSE Center for Applied Research (ECAR) Retrieved from: http://www.educause.edu/ecar

Stewart, B. L., Goodson, C. E., Miertschin, S. L., Norwood, M. L., \& Ezell, S. (2013). Online student support services: a case based on quality frameworks. Journal of Online Learning and Teaching, 9(2), 290-303.

Williams, J., \& Chinn, SJ (2009). Using web 2.0 to support the active learning experience. Journal of Information Systems Education, 20(2), 165-174. Retrieved from https://www.learntechlib.org/p/105682/.

Wilson, C. D., Taylor, J. A., Kowalski, S. M., \& Carlson, J. (2010). The relative effects and equity of inquiry based and commonplace science teaching on student's knowledge, reasoning, and argumentation. Journal of Research in Science Teaching, 47, 276-301.

Yıldırım, A. ve Şimşek, H. (2013). Sosyal Bilimlerde Nitel Araştırma Yöntemleri [Qualitative research methods in the social sciences]. Ankara: Seçkin Publ. 
Yükseltürk, E., Altık, S., \& Üçgül, M. (2017). Evaluation of a scientific activity about use of web 2.0 technologies in education: the participants`views. Journal of Instructional Technologies and Teacher Education, 6 (1) , 1-8.

Zhao, H., Yang, L., \& Wang, Y. (2010. The personal learning environment (ple) based on web2.0. 2nd Symposium on Web Society, Beijing, 22-25, doi:10.1109/SWS.2010.5607483 